\title{
Electrochemical assessment of magnetite anticorrosive paints
}

\author{
D.M. Escobar", C. Arroyave*, F. Jaramillo", O.R. Mattos", I.C. Margarit** \\ and J. Calderón**
}

\begin{abstract}
With the purpose of deepening in the understanding of the mechanisms of protection of anticorrosive pigments based on iron oxides, this work has been carried out on the production of pure magnetite, and copper and chromium doped magnetite, which were evaluated by different characterization techniques. The paints were prepared with a solvent less epoxy resin maintaining the Pigment Volume Content near the Practical Critical value (CPVC), established for each pigment. The paints were applied on polished steel and monitored with electrochemical techniques at total immersion conditions. Permeability and impedance measurements of free films were also done. Impedance data were simulated with the Boukamp software. Results show that the paints pigmented with doped magnetite present better behavior than a paint prepared with commercial hematite.
\end{abstract}

Keywords Anticorrosive paints. Doped magnetite. Hematite. Permeability. Impedance.

\section{Evaluación electroquímica de pinturas anticorrosivas con magnetita}

\begin{abstract}
Resumen Con el propósito de profundizar en el entendimiento de los mecanismos de protección de los pigmentos anticorrosivos a base de óxidos de hierro, se sintetizaron y caracterizaron magnetitas puras y dopadas con cobre y cromo, con las cuales se prepararon pinturas anticorrosivas que fueron evaluadas en ensayos acelerados de campo y laboratorio. Las pinturas fueron especialmente preparadas con una resina libre de solvente manteniendo la Concentración Pigmentaria en Volumen cercana al valor Crítico (CPVC), establecida para cada pigmento. Las pinturas fueron aplicadas sobre acero pulido y evaluadas con técnicas electroquímicas en condiciones de inmersión total. Para complementar el estudio se realizaron medidas de permeabilidad e impedancia sobre las películas libres. Los datos de impedancia se simularon con el programa' Boukamp. Los resultados muestran que las pinturas pigmentadas con magnetitas dopadas presentan mejor comportamiento que las preparadas con hematita comercial.
\end{abstract}

Palabras clave Pinturas anticorrosivas. Magnetitas dopadas. Hematita. Permeabilidad. Impedancia.

\section{INTRODUCTION}

The big cost inflected to companies due to deterioration of the industrial equipments caused by the corrosive action of the atmosphere surrounding such installations, has lead investigators to the production of better systems of surface protection that with easy application and low cost assure the conservation of these equipments.

In this sense, it is required that anticorrosive pigments should be environmentally accepted, being this one of the biggest necessities that producers of pigments have at the moment. Among many of the pigments used with this aim, the iron oxides, that besides of being cheap, they seem to satisfy the requirements for anticorrosive protection; an example of these pigments is magnetite.

In the present work it has been evaluated pure magnetite and copper and chromium doped magnetite as anticorrosive pigments, by means of electrochemical techniques, a series of laboratory tests were developed for it.

$\left({ }^{*}\right)$ Corrosion and Protection Group. University of Antioquia. PO Box 1226. Medellin (Colombia).

$(* *)$ Corrosion Laboratory Manuel Castro. PEMM/COPPE/UFRJ. PO Box 68.505. Rio de Janeiro (Brazil). 


\section{EXPERIMENTAL PROCEDURE}

Pure magnetite, 1 and 5 atomic percent copper and chromium doped magnetite were synthesized, following a similar method to the one described by Schwertmann and Cornell ${ }^{[1]}$. These magnetite compounds were utilized to paint preparation, and a commercial paint containing hematite was used as a reference. For the preparation of the paints solvent less epoxy resin was employed adding the pigment until reaching to the CPVC.

The films were applied with a paintbrush to 1010 steel specimens polished with sandpaper 100 and degreased with toluene. Free films under CPVC adding $10 \%$ in excess of resin were also prepared. The thickness of the free films and of the paint applied on steel are presented in the table I.

Two types of steel samples were used, one of $22.0 \mathrm{~cm}^{2}$ of area on which incisions of $1.5 \mathrm{~cm}$ were made, and the second of $165.13 \mathrm{~cm}^{2}$ with eight steel electrodes of $4 \mathrm{~mm}^{2}$ in area embedded in the metal/film interface.

Impedance measurements were carried out in the steel samples with embedded electrodes, using a 3 electrodes traditional cell with the steel sample as working electrode, a calomel saturated electrode as reference and a titanium electrode covered with oxides of strange lands as auxiliary, and using a potenciostato-galvanostato Omnimetra PG19 and a TFA Solartron IF 1254.

Additionally permeability measurements were made to the free films and the potential monitored during a month for the samples with incision which were immersed in an accelerated solution. All the measurements were carried out in $\mathrm{NaCl} 10^{-2} \mathrm{M}$ solution at room temperature and pH 6.5.

\section{RESULTS}

Figure 1 shows hematite and pure magnetite paints before and after removing the film. The hematite paint presented a great quantity of formed bladders and the formation of spots of corrosion on the substratum. Whereas, the pure magnetite paint presented a better behavior with smaller quantity of bladders and almost any corrosion on the substratum, better behavior was showed by the other copper and chromium doped magnetite films.

Figure 2 shows the evolution potential with and without incision samples during the time of testing. The curves of the samples with incision present a typical behavior with an initial stage of potential fall and later the progressive increase of it; while in the samples without incision is observed that the paints of pure and $1 \%$ chromium and $5 \%$ copper doped magnetite present an potential increase, in comparison, for the hematite and $1 \%$ copper doped magnetite the increase was smaller and much slower.

The evolution of the corrosion potential of a metal with time has been related to its corrosive behavior in a certain medium. In this way, negative values of potential would indicate the presence of corrosion, while nobler potentials would be related to the formation of a layer of stable corrosion products that give to the metal certain protection, which is limited by the $\mathrm{pH}$ conditions and the nature of the electrolyte.

Some authors ${ }^{[2]}$ have related the increase of the potential of the painted metallic substrate to bigger resistances of the film, suggesting that the high electrolytic resistances of the film introduce an ohmic fall of the potential among the anodic and

Table I. Types of pigments and thickness of dry films

Tabla I. Tipo de pigmentos y espesores de película seca obtenidos

\begin{tabular}{|c|c|c|c|}
\hline \multirow[t]{2}{*}{ Sample } & \multirow[t]{2}{*}{ Pigment } & \multicolumn{2}{|c|}{ Average of thikness of dry films $(\mu \mathrm{m})$} \\
\hline & & On steel & Freestanding film \\
\hline $\mathrm{M} 1 \% \mathrm{Cu}$ & Magnetite doped with $1 \%$ cooper & 57.8 & 125.0 (< cpvc) \\
\hline M5 \%Cu & Magnetite doped with $5 \%$ cooper & 62.8 & $124.4(<\mathrm{cpvc})$ \\
\hline $\mathrm{M} 1 \% \mathrm{Cr}$ & Magnetite doped with $1 \%$ chromium & 69.5 & N.D \\
\hline $\mathrm{M} 5 \% \mathrm{Cr}$ & Magnetite doped with $5 \%$ chromium & N.D & 107.8 (сpvc) \\
\hline M pure & Pure magnetite & 76.0 & 115.0 (< cpvc) \\
\hline Hem. & Hematite & 82.7 & 140.0 (сpvc) \\
\hline
\end{tabular}




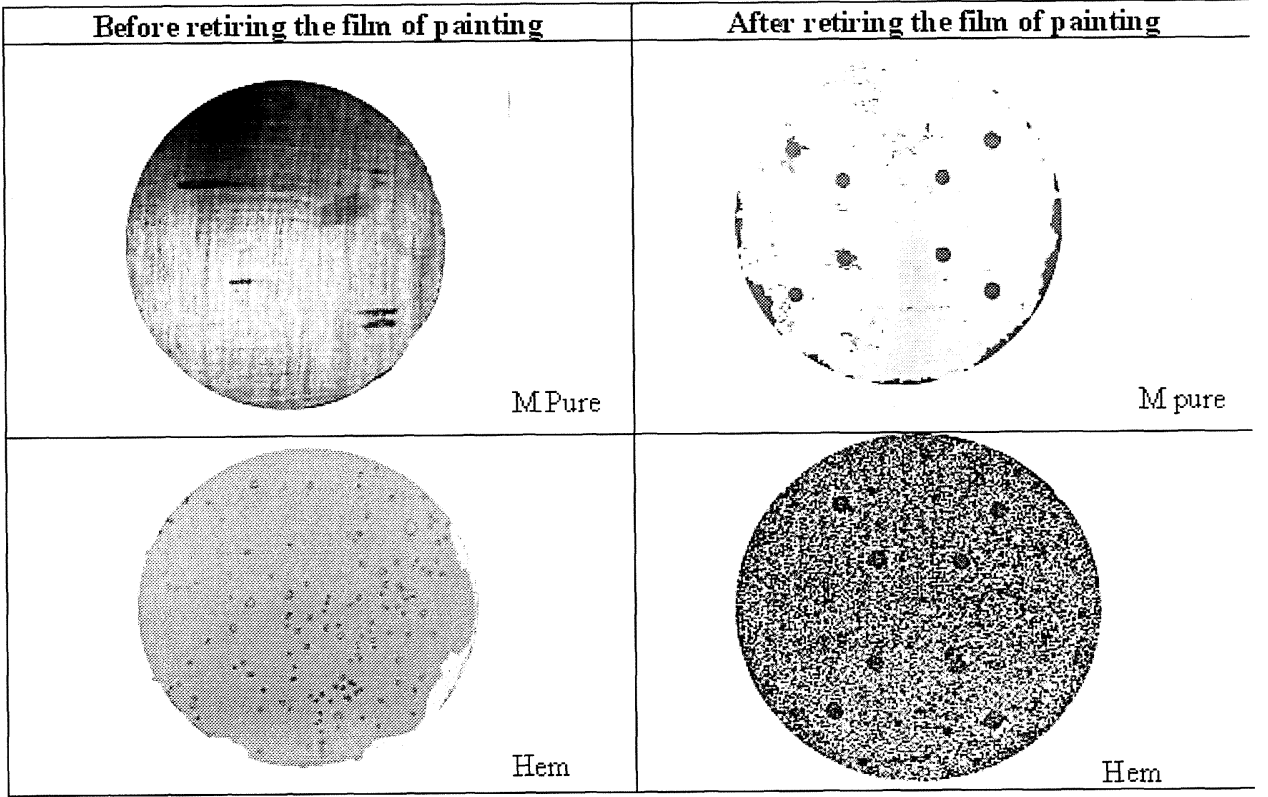

Figure 1. Sample painted with pure magnetite and hematite before and after retreat film.

Figura 1. Muestras pintadas con magnetita pura y hematita antes y después de retiraada la película.
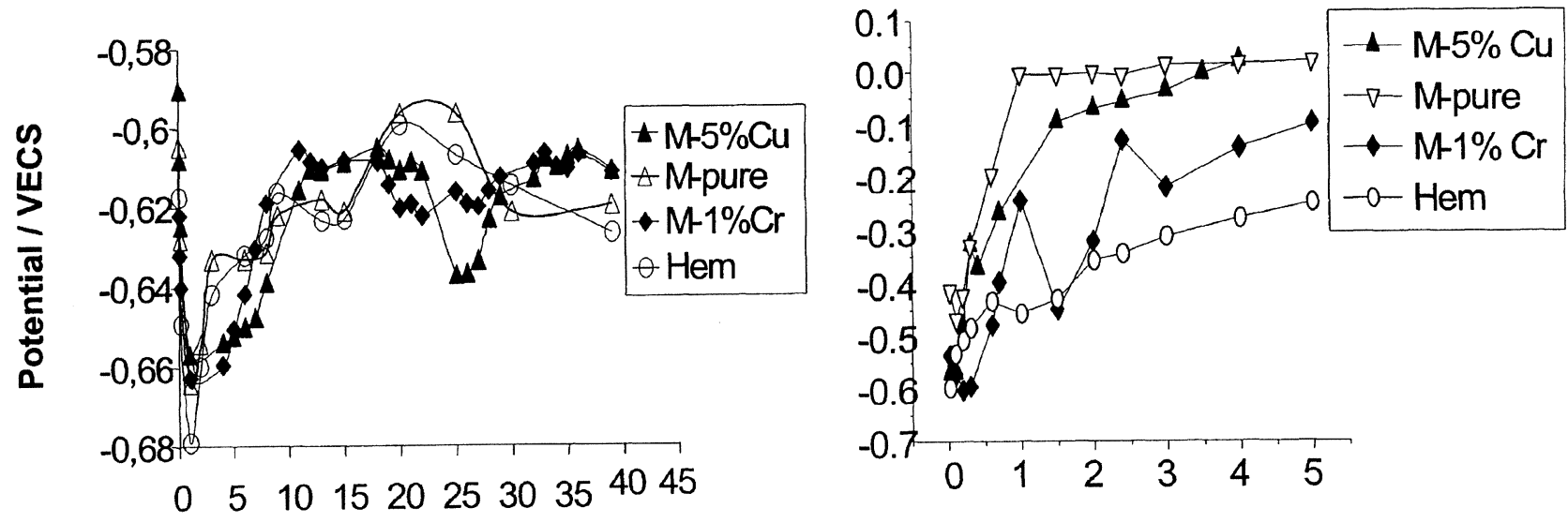

Time / days

a)

b)

Figure 2. Evolution of the potential in samples: a) with incision, b) without incision.

Figura 2. Evolución del potencial en muestras: a) con incisión, b) sin incisión.

cathodic points. In paints with active pigmentation, the variation of the potential is in general related to the inhibition mechanism. In the case of the paints in the present study is not exactly known which is the neither roll of the doping or the magnetite. For this reason, to interpret those curves it is necessary to carry out complementary studies.
Figure 3 shows the impedance diagrams of hematite films and pure and doped magnetites for different times. In general terms, the diagrams present flattening and at least two constants of time can be seen. In the pure magnetite can be observed at least two not very well defined, while the hematite diagrams show a single one very well defined. In the curves of the doped paints with 

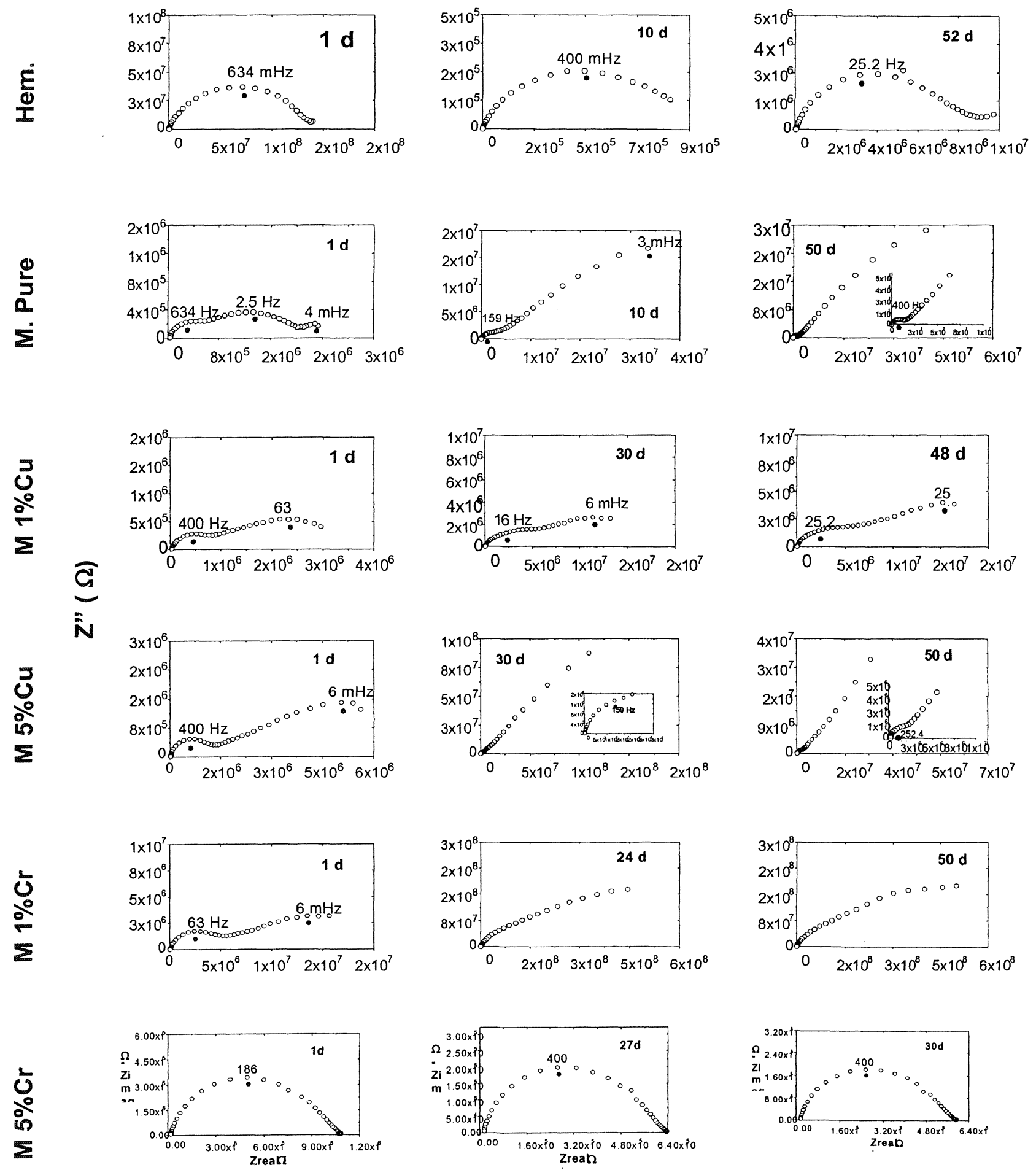

\section{$Z^{\prime}(\Omega)$}

Figure 3. Impedance diagrams for the several studied samples.

Figura 3. Diagramas de impedancia para las diferentes muestras estudiadas.

copper very similar behaviors are observed between them with more than one capacitive arch, while in the paints doped with chromium a difference is observed from the first day of immersion.
The water permeation in the film is responsible for stabilizing the corrosion processes in the metallic substratum and for decreasing some of the mechanical and electrical properties of the film ${ }^{[3-5]}$. 
As shown in figure 4 , all paints present similar water permeation. It can be observed that the permeability of the film of pure magnetite is bigger than the one shown by the doped magnetite. This suggests that there is an action of the doping in the decrease of the permeability.

In the evaluation of paints with electrochemical impedance is common to associate the arch to high frequencies with the properties of the film ${ }^{[6}$ and 7$]$. In figure 5 , the variation of resistance and capacitance with time, is presented, associated to the first arch of the experimental diagrams of impedance. (The resistance and capacitance parameters of the free films were determined assuming only one total arch in the diagram of impedance). It is observed that the resistance in the magnetite films is smaller than in the hematite films, as it was expected because the magnetite is known as a semiconductor. For this reason, the behavior with time of the resistance is similar in the three films, being observed a fall in the initial stages and later to be stabilized to remain constant after the fourth day.

The capacitance of chromium doped magnetite presents a diminution in the initial stages which later stops and became stable, while in the hematite film the classic behavior of paints is presented, working as a barrier with increasing capacitance, followed by a plateau. The behavior of the doped magnetite is interesting, because smaller capacitance values are generally associated to a better behavior of the paint ${ }^{[5]}$. Keeping in mind the form of the experimental diagrams given by the different samples, it is observed as minimum two constants of time and in certain cases three well differentiated. A simulation of the diagrams of impedance carried out with a specialized software ${ }^{[8]}$ considering three capacitive arches, the first two arches corresponding to high frequencies would

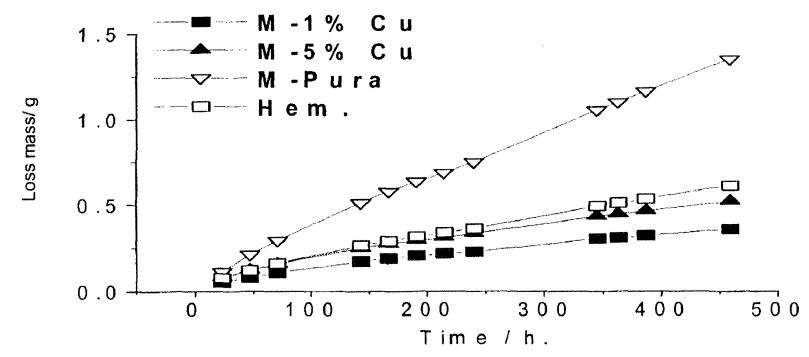

Figure 4. Water permeability for the films of hematite and pure and doped magnetite.

Figura 4. Permeabilidad al agua de películas libres de hematita y magnetitas pura y dopadas.

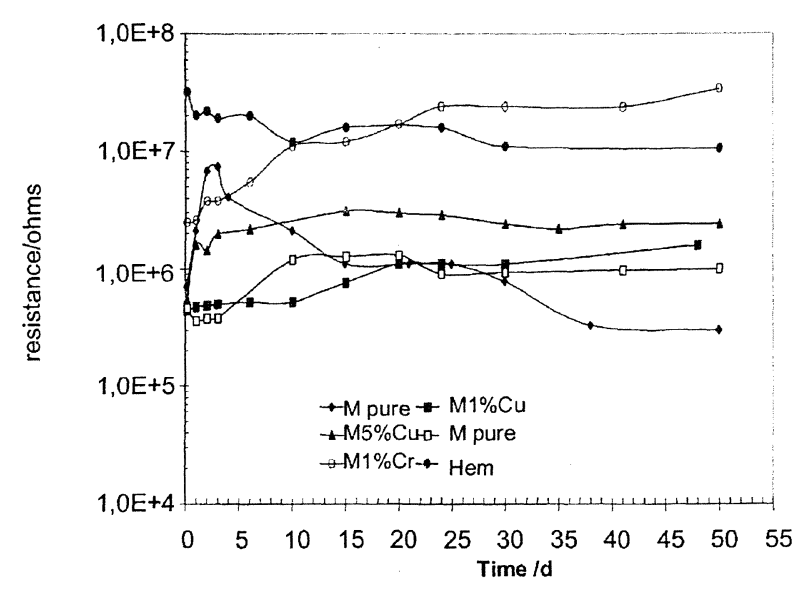

a)

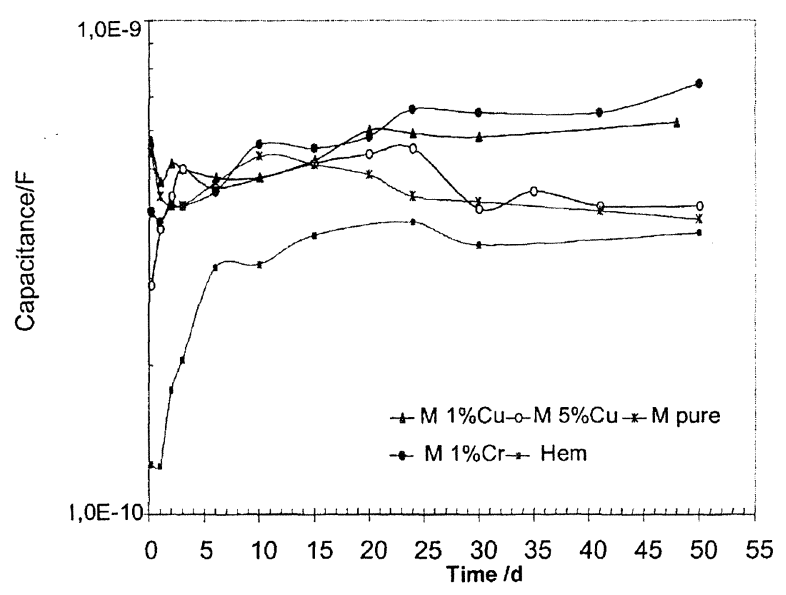

b)

Figure 5. Variation of a) the resistance and b) the capacitance with the time.

Figura 5. Variación de a) la resistencia y b) la capacitancia con el tiempo.

correspond to the film properties and the third to faradaic processes at the metal/film interface.

The simulation of the impedance diagrams was made having as maximum $5 \%$ error in relation to the experimental diagrams. In figure 6 the variation of resistance and capacitance of the three capacitives arches is presented, which was obtained from the simulation. Can be observed that there is great variation in the resistances $\{\mathrm{R} 1\}$ and $\{\mathrm{R} 2\}$ (corresponding to the first and second arch respectively) in the initial stages, but with the increase of time the variation decrease.

The resistance $\{R 1\}$ is very similar for all the paints, but it can be appreciated a bigger stability and a light trend to ascend in the doped magnetite. Something similar happens to resistance $\{R 2\}$, but 

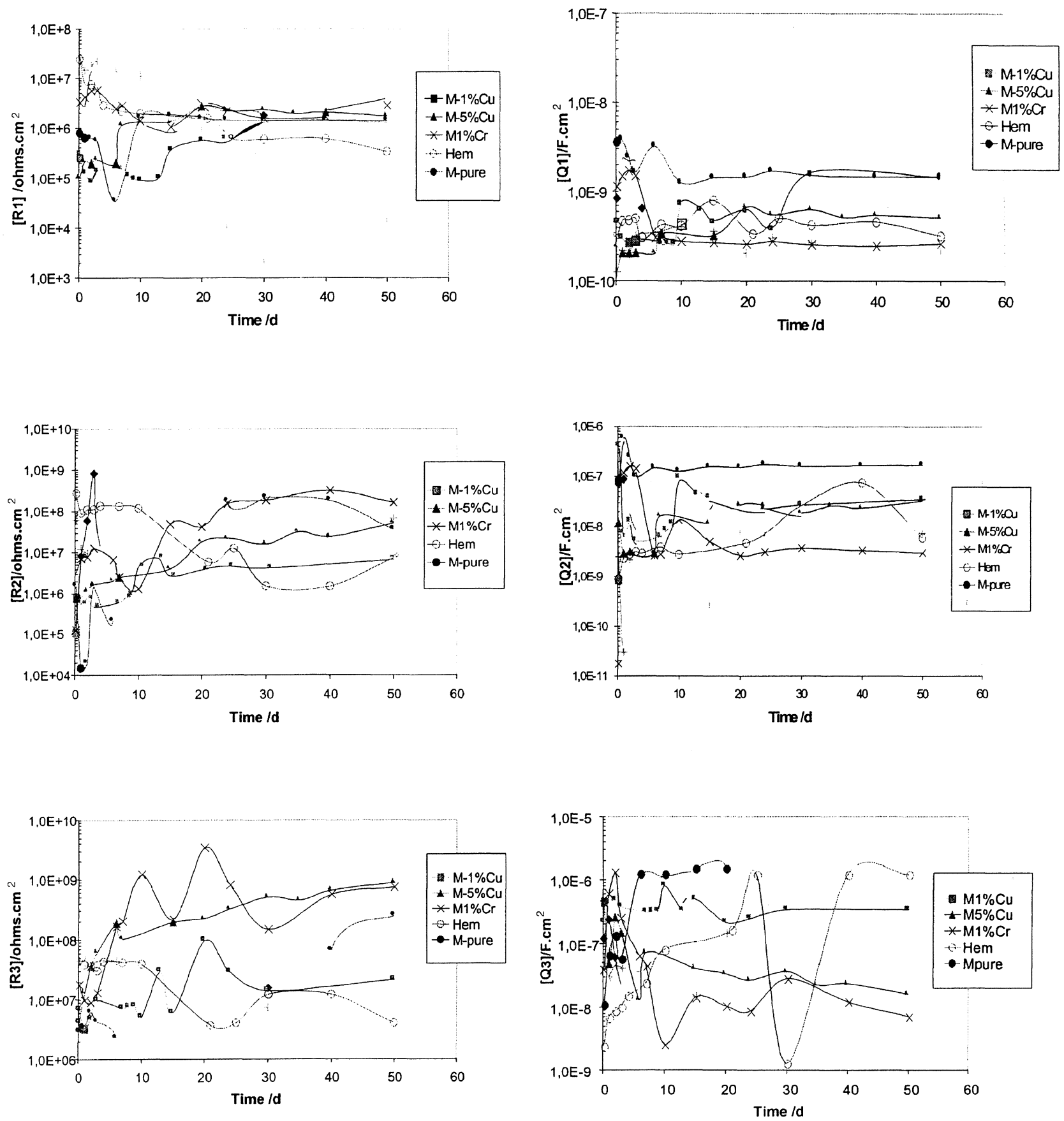

\section{Resistances}

\section{Capacitances}

Figure 6. Variation with the time of resistance and capacitance values obtained by simulation with Boukamp software for a capacitive arches system.

Figura 6. Variación de la resistencia y la capacitancia con el tiempo para el sistema de arcos capacitivos obtenido de la simulación con el software Boukamp.

in a wider range of values. In resistance $\{\mathrm{R} 3\}$, corresponding to faradaic processes at the metal/film interface, the behavior observed present bigger differences between the resistances, where the smallest resistances are for the hematite paints and the biggest for the $5 \%$ Cooper and $1 \%$ chromium doped magnetites. It seems that with this resistance it is possible to appreciate more clearly the action of the doping. These results agree with the visual inspection carried out in the 
samples after removing the film, where the magnetite paints presented few signs of corrosion on the metallic substrate.

The capacitance for the first arch $\{Q 1\}$, presents little variation for the different paints. The capacitance for the second arch $\{\mathrm{Q} 2\}$, contrary to the previous one, presents bigger variability for the hematite paints than for the magnetite paints. In the capacitance $\{Q 3\}$ a great variation is appreciated in the hematite paints for the time of test with trend to increase, while for the magnetite paints the variation is smaller and with a trend to decrease, this situation agrees with that obtained in the resistances $\{R 3\}$ and with results of the visual inspection.

\section{CONCLUSIONS}

- The magnetite paints present better anticorrosive behavior that the commercial hematita paints.

- The magnetite pigment apparently exercises a stabilizing action on the electric properties of the film.

- The action of the copper and the chromium on the magnetite seems to be in the metal/film interface, without knowing yet the protection mechanism of them.

\section{Acknowledgements}

Authors are grateful for financial support from FUJB and CNPq (Brazil) and CODI (Colombia).

\section{REFERENCES}

[1] C.P. MARGARIT and O.R. MATTOS, Electrochem. Records. 44 (1998) 363-371.

[2] S.V. YaKubovitch, Proc. $6^{\text {th }}$ Int. Conf. Electrodepos., 1969, p. 321.

[3] S.A. LindGVIST, Corrosion 412 (1985) 69-75.

[4] E. Westing, Doctoral Thesis, Centers for Coating Research, Technical University of Delft, 1992.

[5] W. BOSH and W. FUNKE, Proc. 20 th FATIPEC, Nice, France, 1990.

[6] J. Hollander, E. Ludwig and S. Hillebrand, Fifth International Tin Plate Conference, England, 1992, paper 25.

[7] F. MAnSfeld, M.W. Kending and S. TSAI, Corrosion 389 (1982) 478-483.

[8] B.A. BoukAmp, Equivalent Circuit. Manual AC-Immitance Dates Analysis System, Netherlands, 1989. 